\title{
PERBANDINGAN LAJU ALIR SALIVA LANSIA PENDERITA DIABETES MILETUS PENGGUNA DAN BUKAN PENGGUNA GIGI TIRUAN LEPASAN
}

\author{
Mayang Pramudya Sari*, Sri Wahyuningsih Rais**, Siti Rusdiana Puspa Dewi***
}

\begin{tabular}{c} 
Keywords: \\
diabetes miletus, \\
gigitiruan, laju alir, \\
lansia \\
\hline
\end{tabular}

\section{ABSTRACT}

Introduction: Older people are often proportional to the loss of teeth and reduced some body functions, such as decreased salivary flow rate. Systemic diseases such as diabetes that are common in the elderly lead to the decrease of salivary production. The use of denture is reported to increase the salivary flow rate.

Methods: This study was an analytic survey with purposive sampling design involving 40 elderly people with diabetes mellitus with age range 45-59 years. Samples divided into two groups, group 1 was using removable denture, while group 2 was not using removable denture. Unstimulated saliva was collected by spitting method for $5 \mathrm{~min}$. Salivary flow rate is obtained by measuring saliva volume in $\mathrm{ml} / \mathrm{min}$. Data were analyzed using unpaired $t$-test with significance level $p<0.05$.

Results: The results showed that elderly people with diabetes mellitus using removable denture had higher salivary flow rate than not using removable denture significantly.

Conclusion: the use of removable denture in elderly diabetic people is able to increase the salivary flow rate.

\section{PENDAHULUAN}

Proses menua merupakan proses alami yang dihadapi oleh manusia. Manusia akan mengalami perubahan melalui tahap-tahap perkembangan seiring dengan berjalannya waktu ${ }^{1}$. Menurut World Health Organization (WHO), usia lanjut terbagi menjadi beberapa golongan yaitu usia pertengahan (middle age) kelompok usia 45-59 tahun, usia lanjut (elderly) kelompok usia 60-74 tahun, usia lanjut tua (old) kelompok usia antara 75-90 tahun, usia sangat tua (very old) kelompok usia diatas 90 tahun ${ }^{1,2}$. Proporsi jumlah lansia terus bertambah di seluruh dunia, terutama di negara berkembang. Kelompok lansia berkembang lebih cepat dibandingkan kelompok usia lainnya. Secara global, jumlah penduduk berusia 60 tahun ke atas mencapai 600 juta dan akan menjadi 2 kali lipat pada tahun 2025. Pada tahun 2050 akan menjadi 2 milyar dan 80\% diantaranya bermukim di negara berkembang 2 . Penelitian sebelumnya menyimpulkan bahwa prevalensi kehilangan gigi pada lansia cukup tinggi ${ }^{3}$. Menurut survey Riskesdas pada tahun 2013, kehilangan gigi menurut kelompok usia 4554 tahun sebesar 1,3\%, usia 55-64 tahun sebesar $4,2 \%$, sedangkan pada kelompok usia lebih dari 65 tahun, kehilangan gigi mencapai 17,1\%. Peningkatan jumlah kehilangan gigi akan berdampak pada kebutuhan akan pemakaian gigi tiruan 4 . Penurunan sekresi saliva pada kelompok lanjut usia (lansia) akan mengalami penurunan karena adanya penurunan jumlah sel asini. ${ }^{5}$ Kemampuan produksi saliva normal sekitar 500-

* Mahasiswa Program Studi Kedokteran Gigi, Fakultas Kedokteran, Universitas Sriwijaya, Inderalaya

** Departemen Prostodonsia, Program Studi Kedokteran Gigi, Fakultas Kedokteran, Universitas Sriwijaya, Inderalaya

*** Departemen Biomedik Program Studi Kedokteran Gigi, Fakultas Kedokteran, Universitas Sriwijaya, Inderalaya Korespondensi : sitirusdiana@fk.unsri.ac.id 
$650 \mathrm{ml} /$ hari $^{5,6}$. Produksi saliva yang berkurang selalu disertai dengan perubahan dalam komposisi saliva, sehingga dapat mengakibatkan sebagian besar saliva tidak berfungsi secara normal yang akhirnya menyebabkan berbagai keluhan di dalam rongga mulut, salah satunya mulut kering atau xerostomia ${ }^{6}$.

Xerostomia juga merupakan salah satu manifestasi oral dari diabetes melitus (DM) ${ }^{7}$. Pada penderita DM, laju alir saliva mengalami penurunan akibat gangguan sekresi glandula submaksilaris dan parotis ${ }^{7}$. Laju alir saliva yang tidak mencukupi memiliki pengaruh besar pada retensi dan stabilitas gigi tiruan, sehingga dapat menghambat proses pengunyahan dan penelanan ${ }^{6,7}$. Perawatan menggunakan gigi tiruan lengkap pada pasien DM memerlukan perhatian khusus agar dapat berfungsi dengan baik. Terdapat 4 faktor penting agar gigi tiruan lengkap dapat berfungsi dengan baik yaitu, dengan adanya cukup dukungan prosesus alveolaris, retensi, keseimbangan otot, dan keseimbangan

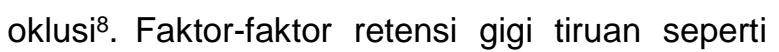
adhesi, kohesi, tegangan permukaan, dan daya tarik menarik kapiler terjadi oleh karena adanya saliva di dalam rongga mulut ${ }^{7}$. Saliva juga berfungsi sebagai lubrikan dan bantalan antara basis gigi tiruan dan jaringan lunak ${ }^{9}$. Pemakaian gigi tiruan lepasan dapat meningkatkan laju alir saliva. Kawahara menyimpulkan bahwa penggunaan gigi tiruan sebagian lepasan dapat meningkatkan laju alir saliva tidak terstimulasi. ${ }^{10}$ Sonthalia dkk menyatakan bahwa pemakaian gigi tiruan lepasan meningkatkan laju alir saliva secara signifikan setelah 3 bulan pemakaian ${ }^{11}$. Berbeda dengan penelitian diatas, Nakayama dkk menyebutkan bahwa tidak terdapat perbedaan laju alir saliva pada pengguna gigi tiruan lepasan pada penderita DM dengan yang sehat setelah 1-3 bulan pemakaian ${ }^{12}$. Penelitian lain yang dilakukan oleh Breseghelo dkk, mengenai perubahan saliva setelah insersi gigi tiruan pada pasien edentulous. Hasil penelitian tersebut menunjukkan tidak ada perbedaan yang signifikan terhadap nilai laju alir saliva $^{13}$.

Oleh karena itu penelitian ini bertujuan untuk mengetahui perbandingan laju alir saliva pada lansia penderita diabetes melitus yang menggunakan dan yang tidak menggunakan gigi tiruan lepasan

\section{METODE PENELITIAN}

Jenis penelitian ini adalah penelitian survei analitik dengan desain cross sectional. Teknik pengambilan sampel dalam penelitian ini adalah purposive sampling. Penelitian ini dilakukan di Poli Penyakit Dalam Rumah Sakit Umum Pusat Mohammad Hoesin Palembang. Populasi penelitian ini adalah keseluruhan pasien lansia di Poli Penyakit Dalam Rumah Sakit Umum Pusat Mohammad Hoesin Palembang, yang menderita penyakit DM baik yang menggunakan gigi tiruan lepasan (GTL dan GTSL) dan yang tidak menggunakan gigi tiruan, berusia dari 45-59 tahun, menggunakan gigi tiruan lengkap atau gigi tiruan sebagian lepasan pada rahang atas (Kennedy klas I atau II) lebih dari 3 bulan yang dibuat oleh dokter gigi, dan yang tidak menggunakan gigi tiruan, serta menderita penyakit diabetes melitus tipe 2 . Sampel perokok, mengkonsumsi minuman beralkohol, menopause, pernah dilakukan bedah pada kelenjar saliva, dan sedang menjalani radioterapi di bagian kepala dan leher dikeluarkan dari penelitian. 
Penelitian ini telah melalui uji kelayakan etik yang dilakukan oleh Komisi Etik Penelitian Rumah Sakit Umum Pusat Mohammad Hoesin dari Fakultas Kedokteran Universitas Sriwijaya dengan sertifikat persetujuan etik No. 426/kepkrsmhfkunsri/2017.

\section{Prosedur penelitian}

Persiapan sampel penelitian, sebelum dijadikan sampel penelitian, sampel diidentifikasi sesuai dengan kriteria-kriteria yang sudah ditentukan oleh peneliti. Kemudian peneliti akan menjelaskan mengenai tujuan dari pemeriksaan yang akan dilakukan oleh peneliti. Setelah sampel mengerti dan menyetujui tindakan yang akan dilakukan maka sampel akan menandatangani informed consent. Pengambilan saliva dilakukan pukul 09.00-12.00. Pada sampel yang menggunakan gigi tiruan lepasan maka diinstruksikan untuk menggunakan gigi tiruan lepasan saat pengambilan saliva. Sampel penelitian diinstruksikan untuk tidak makan dan tidak minum satu jam sebelum pengukuran aliran saliva. Pengambilan saliva tidak terstimulasi dilakukan dengan menggunakan teknik spitting. Sampel penelitian diinstruksikan posisi duduk dengan menundukkan kepalanya $\pm 45^{\circ}$ terhadap lantai, menampung saliva tanpa stimulasi selama satu menit di dalam rongga mulut, kemudian setelah satu menit diludahkan ke dalam centrifuge tube melalui corong. Pengambilan dilakukan sebanyak lima kali selama lima menit. Saliva yang terkumpul dihitung ke dalam satuan millimeter per menit. Pada laju alir saliva yang normal tanpa stimulasi $\pm 0,3 \mathrm{ml} /$ menit.

\section{Analisa Statistik}

Data diuji dengan uji normalitas ShapiroWilk dan uji homogenitas Levene's test. Uji normalitas dan uji homogenitas didapatkan $p$ value $>0,05$ maka data tersebut berdistribusi normal dan memiliki varian yang sama. Apabila data berdistribusi normal dan memiliki varian yang sama, selanjutnya dilakukan pengolahan data dengan Independent sampel t-test. Pengolahan data dilakukan dengan menggunakan software SPSS versi 20 . Nilai kemaknaan yang ditetapkan adalah $\mathrm{p}<0,05$.

\section{HASIL PENELITIAN}

Empat puluh sampel penelitian didistribusikan berdasarkan usia, jenis kelamin, lamanya menderita diabetes melitus, dan lamanya menggunakan gigi tiruan lepasan. Distribusi sampel tersebut dapat dilihat pada tabel 1.

Tabel 1 menunjukkan pada kelompok menggunakan gigi tiruan lepasan sebagian besar sampel berjenis kelamin laki-laki. Pada kelompok yang menggunakan gigi tiruan sebagian besar menderita DM $\leq 3$ tahun, sedangkan kelompok yang tidak menggunakan gigi tiruan menderita DM $\geq 3$ tahun. Lama penggunaan gigi tiruan sebagian besar lebih dari 3 bulan.

Uji normalitas Shapiro-Wilk dilakukan dengan membandingkan rerata laju alir saliva kelompok yang menggunakan gigi tiruan dan yang tidak menggunakan gigi tiruan sehingga didapatkan semua data berdistribusi normal. Uji homogenitas Levene's juga dilakukan dan didapatkan semua data homogen. Uji normalitas dan homogenitas didapatkan $p$ value $>0,05$, 
kemudian dilakukan uji statistik menggunakan uji $\mathrm{t}$ tidak berpasangan. Perbandingan laju alir saliva pada penderita DM yang menggunakan dan tidak menggunakan gigi tiruan tertera pada tabel 2 .

Tabel 1. Distribusi frekuensi sampel berdasarkan usia, jenis kelamin, lama menderita DM dan lamanya penggunaan gigi tiruan lepasan rahang atas

\begin{tabular}{ccc}
\hline & \multicolumn{2}{c}{ Jumlah sampel (n) } \\
\cline { 2 - 3 } & $\begin{array}{c}\text { Menggunakan } \\
\text { gigi tiruan } \\
\text { lepasan }\end{array}$ & $\begin{array}{c}\text { Tidak } \\
\text { menggunakan } \\
\text { gigi tiruan } \\
\text { lepasan }\end{array}$ \\
\hline Jenis Kelamin & & $11(27,5 \%)$ \\
Laki-laki & $16(40 \%)$ & $9(22,5 \%)$ \\
Perempuan & $4(10 \%)$ & 51 \\
Rerata Usia & 52 & $4(20 \%)$ \\
Lama & & $8(40 \%)$ \\
menderita DM & & $8(40 \%)$ \\
$\leq 3$ tahun & $9(45 \%)$ & \\
$3-5$ tahun & $8(40 \%)$ & \\
$>5$ tahun & $3(15 \%)$ & \\
Lama & & \\
Penggunaan & & \\
gigi tiruan & & \\
$\leq 3$ bulan & 5 (25\%) & \\
$>3$ bulan & $15(75 \%)$ & \\
\hline
\end{tabular}

Tabel 2 menunjukkan perbandingan laju alir saliva, kelompok penderita DM yang menggunakan gigi tiruan laju alir saliva lebih tinggi dibandingkan dengan penderita DM yang tidak menggunakan gigi tiruan. Kemudian dilakukan uji $\mathrm{T}$ tidak berpasangan pada kedua kelompok tersebut dan didapatkan nilai $p=0,00$. Berdasarkan perhitungan tersebut diperoleh bahwa nilai $p<0,05$ yang berarti terdapat perbedaan laju alir saliva pada kedua kelompok tersebut.

Tabel 2 Perbandingan laju air saliva pada penderita DM yang dan tidak menggunakan gigi tiruan lepasan

\begin{tabular}{|c|c|c|c|}
\hline & Rerata & & \\
\hline $\begin{array}{l}\text { Penggunaan } \\
\text { Gigi tiruan }\end{array}$ & $\begin{array}{c}\text { laju alir } \\
\text { saliva } \pm \\
\text { SD } \\
\text { (ml/menit } \\
\text { ) }\end{array}$ & $p$ & $\begin{array}{c}\text { Perbed } \\
\text { aan } \\
\text { rerata }\end{array}$ \\
\hline Menggunakan & $0.33 \pm$ & \multirow{4}{*}{0.00} & \multirow{4}{*}{$\begin{array}{c}0.12 \\
(0.08- \\
0.16)\end{array}$} \\
\hline Gigi tiruan & 0.06 & & \\
\hline Tidak & 021 & & \\
\hline $\begin{array}{l}\text { Menggunakan } \\
\text { Gigi tiruan }\end{array}$ & \pm 0.06 & & \\
\hline
\end{tabular}

Independent $t$ test, $p=0,05 .{ }^{*}$ Signifikan

\section{DISKUSI}

Hasil penelitian pada tabel 1 diatas menunjukkan bahwa jumlah sampel laki-laki baik yang menggunakan maupun yang tidak menggunakan gigi tiruan lebih banyak dibandingkan jumlah sampel perempuan. Akan tetapi penelitian sebelumnya melaporkan bahwa laju alir saliva baik terstimulasi maupun tidak terstimulasi antara laki-laki dan perempuan tidak berbeda secara signifikan ${ }^{14}$. Sehingga faktor jenis kelamin terhadap perubahan laju alir saliva tidak berpengaruh dalam penelitian kali ini. Faktor usia mempengaruhi laju alir saliva ${ }^{15}$. Oleh karena itu, pada penelitian ini, sampel didistribusikan dengan rentang usia yang sama sehingga tidak mempengaruhi hasil penelitian. 
Faktor lainnya yang dapat mempengaruhi hasil penelitian adalah lamanya menderita diabetes ${ }^{16}$. Semakin lama menderita penyakit diabetes, maka semakin banyak pula perubahan yang dapat terlihat dari kelenjar ludahnya ${ }^{16,17}$. Penelitian yang dilakukan Maori-Obradors dkk menyebutkan bahwa kelainan tersebut dapat dikurangi dengan melakukan kontrol terhadap penyakit diabetes dengan baik, sehingga manifestasi oral pada penyakit diabetes dapat diturunkan ${ }^{17}$. Dalam penelitian ini, sampel dipastikan melakukan kontrol rutin terhadap penyakit diabetes yang dideritanya. Lamanya penggunaan gigi tiruan mempengaruhi laju alir saliva. Penelitian terdahulu merangkum bahwa penggunaan gigi tiruan diatas 5 tahun dapat mempengaruhi perubahan laju alir saliva pada penggunanya ${ }^{18}$. Penelitian ini dilakukan pada penderita diabetes dan menggunakan gigi tiruan diatas 3 bulan untuk mengevaluasi perubahan laju alir salivanya.

Lansia penderita DM pada kelompok yang tidak menggunakan gigi tiruan lepasan memiliki rerata laju alir saliva yang lebih rendah dibandingkan nilai normal laju alir saliva yang tidak terstimulasi pada penelitian ini. Hal ini sesuai dengan penelitian Lopez-Pintor dkk bahwa penderita DM memiliki nilai laju alir saliva lebih rendah dari nilai normal ${ }^{19}$. Penurunan laju alir saliva pada penderita DM dapat disebabkan oleh kontrol glikemik yang buruk, mikroangiopati, dan perubahan stuktural kelenjar parotis ${ }^{20}$.

Penderita DM dengan kondisi hiperglikemia dapat meningkatkan fungsi osteoklas dan menurunkan fungsi osteoblas sehingga memicu resorbsi tulang secara cepat yang menyebabkan kegoyangan gigi21. Kehilangan gigi dapat menyebabkan kesulitan dalam mengunyah makanan, berbicara, mengakibatkan gigi migrasi, dan penurunan tulang alveolar pada daerah yang edentulous. Kehilangan gigi lebih dari tiga gigi posterior dalam satu lengkung rahang dapat menganggu sistem mastikasi22. Sawair dkk melakukan penelitian mengenai hubungan antara laju saliva dan jumlah gigi. Hasil penelitian menunjukkan bahwa kehilangan satu sampai lima gigi dapat menurunkan laju alir saliva, dan setiap kehilangan satu gigi berikutnya akan makin menurunkan laju alir saliva ${ }^{23}$

Penurunan laju alir saliva pada penderita DM yang kehilangan gigi dapat diatasi dengan penggunaan gigi tiruan. Kekuatan mengunyah dan menggigit yang didapat dari gigi tiruan berperan dalam sekresi kelenjar saliva yang dapat mengaktivasi reseptor mekanik periodontal mengarah ke peningkatan stimulasi yang selanjutnya meningkatkan laju alir saliva ${ }^{24}$. Hasil penelitian yang telah dilakukan menunjukkan bahwa terdapat peningkatan laju alir saliva pada kelompok yang menggunakan gigi tiruan lepasan. Hal ini sesuai dengan penelitian oleh Muddugangadhar dkk yang menyatakan laju alir saliva lebih tinggi pada kelompok yang menggunakan gigi tiruan dibandingkan kelompok sampel yang tidak menggunakan gigi tiruan ${ }^{25}$. Batisse dkk juga mengatakan bahwa penggunaan gigi tiruan lepasan dapat meningkatkan laju alir saliva, namun tidak mengubah persepsi rasa pada makanan ${ }^{26}$.

Penggunaan gigi tiruan pada rahang atas akan menekan bagian palatal yang dapat menstimulus kelenjar parotis. Hasil penelitian menunjukkan bahwa tidak adanya perbedaan pada laju alir saliva antara pengguna gigi tiruan lengkap dengan gigi tiruan sebagian lepasan di 
rahang atas ${ }^{27}$. Gigi tiruan dianggap sebagai benda asing di dalam rongga mulut yang mempengaruhi psikologi seseorang saat penggunaan gigi tiruan, sehingga produksi laju alir saliva meningkat ${ }^{28}$.

Maheshwari melaporkan terdapat peningkatan laju alir saliva setelah 3 bulan penggunaan gigi tiruan, yang berbeda secara signifikan dibandingkan sebelum insersi gigi tiruan $^{29}$. Gigi tiruan dapat bertindak sebagai stimulan mekanis dan terus berlanjut sehingga meningkatkan laju alir saliva. Penderita DM yang kehilangan gigi sebaiknya menggunakan gigi tiruan untuk meningkatkan laju alir saliva sehingga kualitas hidup pada lansia meningkat.

\section{KESIMPULAN}

Berdasarkan dari hasil penelitian diatas maka dapat disimpulkan bahwa laju alir saliva pada lansia penderita DM yang menggunakan gigi tiruan lepasan lebih tinggi dibandingkan pada lansia penderita DM yang tidak menggunakan gigi tiruan lepasan.

\section{DAFTAR PUSTAKA}

1. Walker KO, Steers N, Liang L, Morales L S, Forge N, Jones L, Brown AF. The vulnerability of middle-aged and older adults in a multiethnic, low-income area: contributions of age, ethnicity, and health insurance. J. Am. Geriatr. Soc. 2010; 58(12): 2416-22

2. Petersen PE, Kandelman D, Arpin S, Ogawa H. Global oral health of older people--call for public health action. Comm. Dent. Health. 2010; 27(2): 257-67
3. Felton D, Cooper L, Duqum I, Minsley G, Guckes A, Haug S. Evidence-based guidelines for the care and maintenance of complete denture. J. Am. Dent. Assoc. 2011; 142: $1-9$

4. Agtini MD. Persentase pengguna protesa di Indonesia. Media penelitian dan pengembangan kesehatan 2010; 20(2): 50-8

5. Choi JS, Park IS, Kim SK, Lim JY, Kim YM. Analysis of age-related changes in the functional morphologies of salivary glands in mice. Arch. Oral. Biol. 2013; 58(11):1635-42

6. Gil-Montoya JA, Silvestre F, Barrios R, Silvestre-Rangil J. Treatment of xerostomia and hyposalivation in the elderly: $A$ systematic review. Med. Oral Pathol. 2016; 1(3):e355-66

7. Hoseini A, Mirzapour A, Bijani A, Shirzad A. Salivary flow rate and xerostomia in patients with type I and II diabetes mellitus. Electron Physician 2017; 9(9): 5244-9

8. Postic SD. Influence of balanced occlusion in complete dentures on the decrease in the reduction of an edentulous ridge. Vojnosanit. Pregl. 2012; 69(12): 1055-60.

9. Villa A, Connell CL, Abati S. Diagnosis and management of xerostomia and hyposalivation. Ther Clin. Risk. Manag. 2015; 11: 45-51

10. Kawara A. The insertion of removable partial denture increases unstimulated salivary flow rates in non-denture wearers. Int. J. Oral. Med. Sci. 2013; 12: 147-53

11. Sonthalia A, Chandrasekaran AP, Mhaske SP, Lau M, Joshy VR, Attokaran G. Comparative evaluation of effect of complete denture wears on the flow rate of saliva in 
both medicated and apparently healthy patients. J. Dent. 2016; 6(3): 219-23

12. Nakayama F, Tanaka J, Tanaka M. Changes in the oral environment after placement of removable dentures in low caries risk patients. J. Osaka Dent. Univ. 2014; 48(2): 87-92

13. Breseghelo MD, Guillo LL, Nogueira TE, Leles CR. Nitric oxide concentration and other salivary changes after insertion of new complete dentures in edentulous subjects. Int. J. Dent. 2016; 2016: 1-6

14. Wiener RC, Mogan S, Swager L, DeBiase C, Lilly CL. Stimulated hyposalivary flow rates in healthcare students in an interprofessional awareness educational program curriculum. J. Biomed. Ed. 2017; 2017: 1-7

15. Karnik AA, Pagare SS, Krishnamurthy V, Vahanwala SP, Waghmare M. Determination of salivary flow rate, $\mathrm{pH}$, and dental caries during pregnancy: A study. J. Indian Aca. Oral. Med. Rad. 2015; 27(3): 372-6

16. Al-Maskari AY, Al-Maskari MY, Al-Sudairy S. Oral Manifestations and Complications of Diabetes Mellitus. Sultan Qobus Univ. Med. J. 2011; 11 (2): 179-86

17. Mauri-Obradors E, Estrugo-Devesa A, JaneSalas E, Vinas M, Lopez-Lopez J. Oral manifestations of Diabetes Mellitus. A systematic review. Med Oral Patol Oral Cir

Bucal. 2017; 22(5): 586-94 